ASEAN Journal of Chemical Engineering 2021, Vol. 21, No. 2, $201-210$

\title{
Evaluation of Drying Air Conditions for Antiozonant Wax Drying Process in the Spray Drying Tower
}

\section{Marcelinus Christwardana *}

Ifa Miftahushudury

Department of Chemical Engineering, Institut Teknologi Indonesia, Jl. Raya Puspiptek Serpong, South Tangerang, Banten, 15314 Indonesia

”e-mail:marcelinus@iti.ac.id; mchristwardana@gmail.com

Submitted 26 February $2021 \quad$ Revised 17 September $2021 \quad$ Accepted 08 October 2021

\begin{abstract}
The drying technique of Antiozonant Wax (AOW) using drying air in the spray drying tower has a considerable effect on the produced AOW powder. In this study, the drying air flow rate was measured in such a way that AOW can transform into a powder with a size of 800 mesh. The diameter and height of the spray drying tower are 1 and $6 \mathrm{~m}$, respectively. Meanwhile, the AOW flow rate to the spray drying tower varies from $100 \mathrm{~kg} / \mathrm{hour}$ to $500 \mathrm{~kg} / \mathrm{hour}$. The intake AOW temperature was $70^{\circ} \mathrm{C}$ and at the outlet was $40^{\circ} \mathrm{C}$, while the drying air temperatures in and out of the spray drying tower were 30 and $55^{\circ} \mathrm{C}$, respectively. From the calculation results, the flow rate of the drying air is directly proportional to the flow rate of the AOW into the spray drying tower but inversely proportional to the speed of the AOW powder down the spray drying tower. In the meantime, the drying period for AOW to become a powder is between $1.033-1.279 \mathrm{~s}$, not significantly different. It gives insight into the need to dry air in the spray drying tower configuration so that the findings will conform to the predetermined requirements.
\end{abstract}

Keywords: Antiozonant, Equipment design, Mass flow rate, Paraffin wax, Spray drying

\section{INTRODUCTION}

Paraffin wax is a soft, colorless solid extracted from petroleum, coal or shale oil, composed of a combination of hydrocarbon molecules comprising between twenty and forty carbon atoms (Freund, 1982) and can be represented as a solid type. Paraffin wax is obtained by a range of methods, including material blending, crystallization, bleaching, filtration, additive mixing, filtration, molding (Sanderson et al., 1988). The product finishing process is carried out after delivery of the paraffin wax product with the requirements set by the factory. Paraffin wax is typically a solid unit where the wax phase is the last to manufacture the material in a solid-state. This method is achieved by molding or printing in a mold of a certain size for some time. Products developed in this solid process include Fully Refined Paraffin Wax, High Semi Refined Paraffin Wax, Semi Refined Paraffin Wax, Yellow Batik Wax, Hard Semi Refined White Wax (Zaky et al., 2007). In 2020, Indonesia exported 9065 tons of paraffin wax, and on the other hand, imports are just 2 tons each year (Trade Map, 2021a; 2021b). Based on the relatively high import and low export numbers, it can be assumed that (i) Indonesia has a strong need for paraffin wax, and (ii) few industries manufacture paraffin wax. It is a fantastic chance to start a paraffin wax plant in Indonesia.

One form of paraffin wax substance is 
antiozonant wax (AOW) (Kamaruddin et al., 2012; Saha et al., 2021). AOW is a substance that can neutralize the effect of ozone gas on rubber and tires (Choi, 1999a; Cataldo, 2018; Cataldo, 2019). The ozone layer is the layer above the earth that protects humans from the sun's damaging rays. However, ozone on earth is toxic to many things, including tires (Ushmarin \& Kavun, 2017). Antiozonant wax is used on tires to mitigate the negative impact of ozone gas on tires and makes the tires tougher and longer-lasting (Choi, 1999b; Sharj-Sharifi et al., 2020). Today's tires can operate in more challenging environments even at higher speeds thanks to the AOW.

This research focuses on producing AOW powder using a spray drying tower. This study aims to develop a suitable spray dryer design that is in compliance with the intended production capacity, so that paraffin wax products meet the acceptable requirements while also saving heat energy by optimizing operating conditions such as contact time and drying air temperature. The paraffin wax collected from the filtration device flows into a holding tank fitted with a heater coil. The temperature is held at a specific temperature, then flows with a pressure pump such that the liquid paraffin wax can rise and reach the spray drying tower. The spray drying tower is fitted with an atomizer of a certain dimension, such as paraffin wax. Which flows from above, does not fall at once but spreads and forms tiny granules. Air is blown from the bottom of the spray drying tower. The aid of a lower temperature air of blower causes the temperature of the AOW to decrease.

\section{MATERIALS AND METHODS}

\section{Operating Condition in Spray Drying Tower}

Spray drying is a process that transforms liquid materials into dried particles by atomizing the solution into a hot drying medium (Keshani et al., 2015). The construction of the spray drying tower for the processing of paraffin wax in powder form with a volume of $100-500 \mathrm{~kg} / \mathrm{hour}$, the temperature of the incoming raw material is $70{ }^{\circ} \mathrm{C}$, and the temperature of the outgoing product is $40^{\circ} \mathrm{C}$. And the temperature of the drying air entering the spray drying tower was $30^{\circ} \mathrm{C}$, while the drying air temperature coming out of the spray drying tower was $55^{\circ} \mathrm{C}$. Low temperature drying is a new technique in the drying process, which is used to minimize damage to the sample content (de Melo Ramos et al., 2019). The flow used is the counter current flow, this type of flow was selected because the counter current flow type has a higher heat transfer efficiency than other types (Zbicinski, 1995; Crowe, 1983).

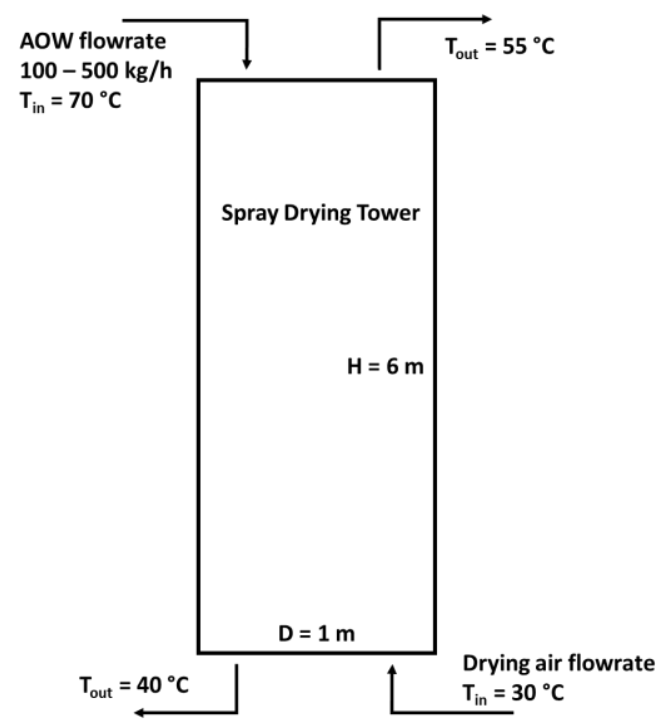

Fig. 1: Schematic of Spray Drying Tower

The desired width and height of the spray drying tower is 1 and 6 meters, with the desired diameter of about 800 mesh of AOW powdered substance. For that, a pneumatic atomizer with a nozzle diameter is 18 microns was selected because it is suitable for the high viscous fluid of AOW (Cheng et al., 
2018). Based on the above information, it is crucial to determine the need for drying air and the time for the product to fall into the spray drying tower. The desired dimension and operating condition of the spray drying tower can be shown in Figure 1 .

\section{Composition, Molecular Weight, and Density of AOW}

The AOW was obtained from a paraffin wax industry in Tangerang, Indonesia and consisted of hydrocarbons with a carbon number of 19 to 50. The composition of each component can be shown in Figure 2. The following equation (1) is used to calculate AOW molecular weight:

$M W_{\text {AOW }}=\Sigma\left(M W_{\text {components }} \times\right.$ composition $)$

The AOW composed of the components of table 1 has an MW of $44572.25 \mathrm{~g} / \mathrm{mol}$.

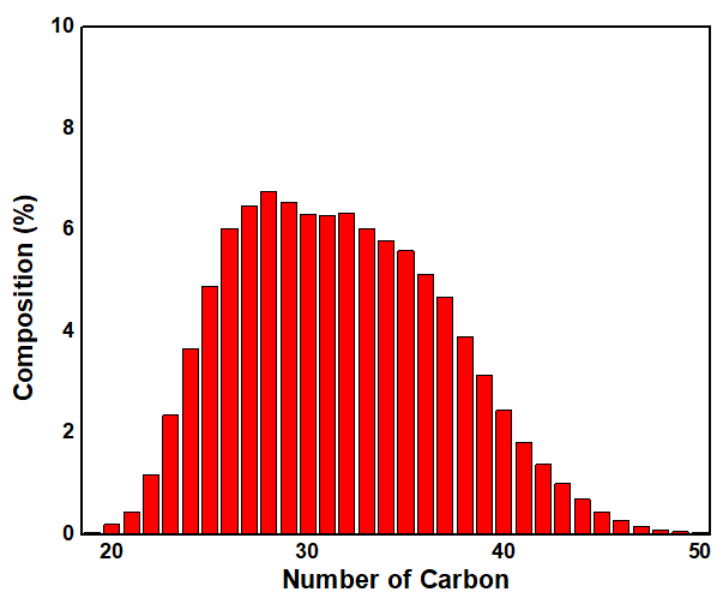

Fig. 2: The composition of hydrocarbons in AOW

The AOW density is obtained using the equation (2) following:

$$
\rho_{\text {AoW }}=\Sigma\left(\rho_{\text {components }} \times \text { composition }\right)
$$

The AOW composed of the components of table 1 has a density of
$79840,13 \mathrm{~kg} / \mathrm{m}^{3}$. The fusion and solidification enthalpies were 7719.92 and 10290.62 $\mathrm{KJ} / \mathrm{mol}$.

\section{Drying Rate Calculation}

It is essential to understand the drying rate of wax antiozonants from the liquid to powder phase. The drying rate was determined by calculating the change in $M C$ across time, expressed in $\mathrm{kg} \mathrm{H}_{2} \mathrm{O} / \mathrm{kg}$ solid/h on a wet basis. It should be noticed that the incoming feed has an oil content of less than $1 \%$, while the powder required to come out of the spray dryer has an oil content in the range of 0.08 $0.1 \%$. The modification of the following equation (3) is used to calculate the drying rate (Sobukola and Olatunde, 2011; Otolowo et al., 2017):

Drying Rate $=\frac{M_{t+d t}-M_{t}}{d t}$

where drying rate is in the $\mathrm{kg} \mathrm{H} \mathrm{H}_{2} \mathrm{O} / \mathrm{kg}$ solid/s, $\mathrm{M}_{t+d t}$ is the oil content at $t+d t, \mathrm{Mt}_{\mathrm{t}}$ is the oil content at time $t$ (drying time), and $d t$ is the change in drying time.

\section{Design Methodology}

Figure 3 depicts an overview of the design strategy employed in this analysis to achieve the target. The calculations in this report were done using the Microsoft Excel 2019 app.

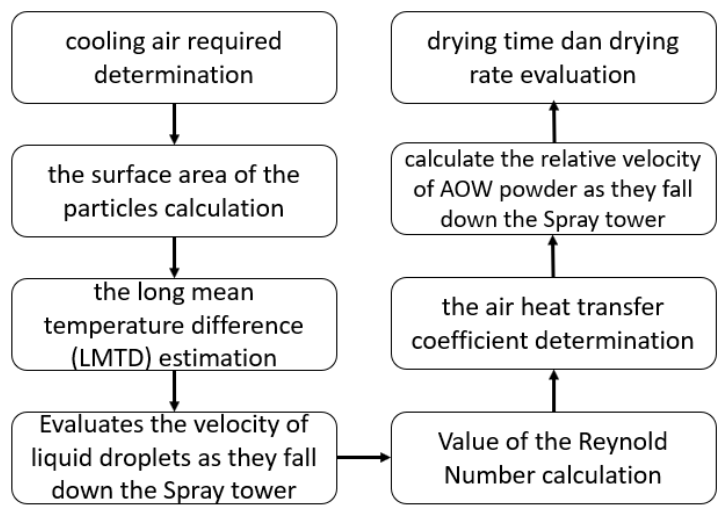

Fig. 3: The design approach used in this study 


\section{RESULTS AND DISCUSSION}

\section{Correlation between AOW Capacity And Flow Rate of Drying Air}

First, the drying air flow rate should be found using the energy balance principle, where $\mathrm{Q}$ drying air should be equal to $\mathrm{Q}$ antiozonant wax. Equation (4) can be used for the calculation of drying air flow rate:

$m_{\text {air }}=\frac{m_{\text {AOW }} \times H_{\text {solidification }}}{C p_{\text {air }} \times \Delta T}$

where $m_{\text {air }}$ is the flow rate of the drying air, maow is the flow rate of the antiozonant wax,

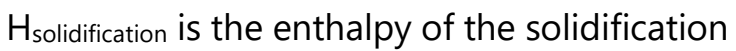
process, $\mathrm{Cp}_{\text {air }}$ is the heat conductivity of the air, and $\Delta T$ is the temperature difference of drying air coming in and out the spray drying tower.

The correlation between the antiozonant wax capacity of the spray drying tower and the drying airflow of the under-sided spray drying tower is seen in Figure 4. With the increase in capacity or mass flow rate of the antiozonant wax, the drying air rate increases. The required mass flow rate of the drying air at an antiozonant wax rate of $100 \mathrm{~kg} /$ hour is $917.08 \mathrm{~kg} /$ hour, and at $500 \mathrm{~kg} /$ hour antiozonant wax flow rate, the required dryer flow rate was $4585.40 \mathrm{~kg} /$ hour. Increased antiozonant wax flow rate is proportional to the drying air flow rate as per $y=9.17 x$ and would be the same size or uniform for the wax powder antiozonant. The inlet temperature of drying air affects sample density and moisture content, according to Goula and Adamopoulos (2010). The increase in the drying rate of the dryer reduces the sample density by evaporating more water vapor (Walton, 2000). According to Francia et al., $(2016 a, b)$, the nozzle height of the spray dryer determines the particle size of the powder. As the height of the nozzle in the spray dryer is aligned with the height of the spray drying tower, although the height of the spray drying tower and the temperature of the intake air have been set, the dryer air flow rate is the only factor of influence.

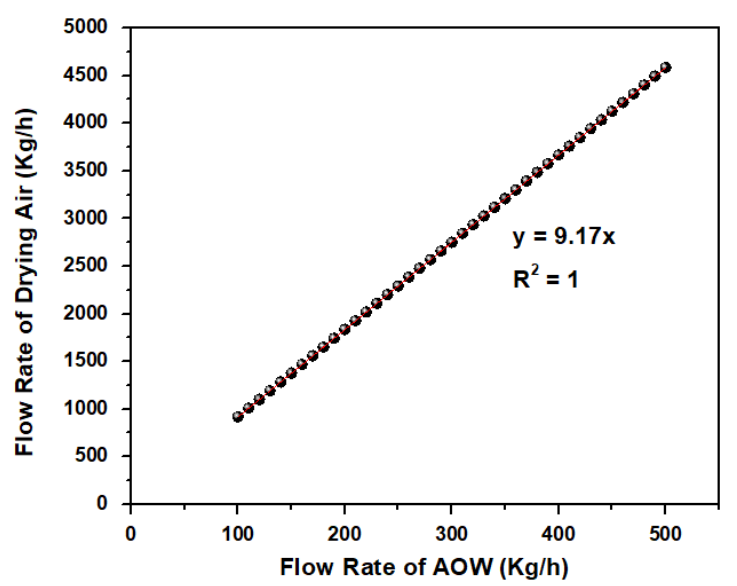

Fig. 4: The relationship between AOW capacity and flow rate of drying air

\section{Correlation between AOW capacity and velocity of AOW powder}

Several stages were needed to calculate the velocity of the AOW powder across the spray drying tower, including 1) determining the surface area of the particles, 2) calculating the Log Mean Temperature Difference (LMTD), 3) estimating the speed of the AOW drop out of the atomizer, and 4) measuring the heat transfer air coefficient.

The first step of the procedure is to assess the surface area of the AOW powder as a result of the process. The surface area can be determined using the equation (5):

$A=\frac{\Pi \times D_{p}^{2}}{4}$

where $D_{p}$ is the particle diameter of the desired AOW product, that is $0.000018 \mathrm{~m}$. So that the surface area of the product is $2.543 \mathrm{x}$ $10^{-10} \mathrm{~m}^{2}$ after putting it into the equation.

The second step is to determine the LMTD where the measurement of the LMTD 
follows the following equation (6):

$L M T D=\frac{\left(T_{\text {in }} A O W-T_{\text {out }} \text { air }\right)-\left(T_{\text {out }} A O W-T_{\text {in }} \text { air }\right)}{\ln \frac{\left(T_{\text {in }} A O W-T_{\text {out }} \text { air }\right)}{\left(T_{\text {out }} A O W-T_{\text {in }} \text { air }\right)}}$

where the AOW and air values of $T_{\text {in }}$ and $T_{\text {out }}$ can be seen in Figure 1. From these calculations, the LMTD value is $12.33^{\circ} \mathrm{C}$.

The third stage is to measure the velocity of the AOW droplets coming out of the atomizer down the spray drying tower. Equation (7) is used to calculate the velocity of the AOW droplet after leaving the atomizer.

$U_{t}=\sqrt[1.75]{\frac{g \times D_{p} \times\left(\rho_{\text {particle }}-\rho_{\text {air }}\right)}{\rho_{\text {air }}}}$

where Ut is the velocity of AOW droplets leaving the atomizer, $g$ is the acceleration of gravity $\left(9.8 \mathrm{~m} / \mathrm{s}^{2}\right), D_{p}$ is the particle diameter, pparticle is the particle density (79840.131 $\left.\mathrm{kg} / \mathrm{m}^{3}\right)$, and $\rho$ air is the density of air $(1.165$ $\mathrm{kg} / \mathrm{m}^{3}$ ). From this calculation, the Ut value is $6.09 \mathrm{~m} / \mathrm{s}$

The fourth stage is to determine the coefficient of air heat transfer. In this case, it is important to determine the Reynold Number ( $\mathrm{N}_{\mathrm{Re}}$ ) and Prandtl Number ( $\mathrm{N}_{\mathrm{pr}}$ ). Equations (8) and (9) to calculate $\mathrm{N}_{\mathrm{Re}}$ and $\mathrm{NPr}_{\mathrm{r}}$ can be used as follows:

$N_{R e}=\frac{D_{p} \times u_{t} \times \rho_{\text {air }}}{\mu_{\text {air }}}$

$N_{P r}=\frac{C p_{\text {air }} \times \mu_{\text {air }}}{k f_{\text {air }}}$

where kfair is the thermal conductivity of the air $(0.026 \mathrm{~W} / \mathrm{m} . \mathrm{K})$. $\mathrm{N}_{\mathrm{Re}}$ of 6.82 and $\mathrm{N}_{\mathrm{pr}}$ of 0.73 are derived from the two equations. The value of the air heat transfer coefficient ( $h$ ) is then obtained by the following equation (10): $h=\frac{k f_{a i r}\left(2+0.6 N_{R e^{0.5}}^{0.5 N_{P r}}{ }^{0.33}\right)}{D_{p}}$

So that, the value of the air heat transfer coefficient obtained is $2030.56 \mathrm{~W} / \mathrm{m}^{2} . \mathrm{K}$.

The velocity of the AOW powder product down the spray drying tower can be measured by taking into consideration the surface area of the spray drying tower, the volumetric air flow rate and the air blowing velocity. The surface area (Ap) of the spray drying tower is first defined using the equation (11):

$A_{p}=\frac{\Pi \times D^{2}}{4}$

in the case of $D$, the desired diameter of the spray drying tower is $1 \mathrm{~m}$, so the Ap weighs is $0.785 \mathrm{~m}^{2}$. Meanwhile, the volumetric air rate (Qair) is achieved by dividing the mass and density of the air, and by dividing the volumetric airflow rate and the area of the spray drying tower, the air blowing rate $\left(V_{\text {air }}\right)$ is achieved. The AOW powdered product rate down the spray drying tower $\left(\mathrm{V}_{\text {rel }}\right)$ is determined by the extraction of $\mathrm{V}_{\text {air }}$ by $\mathrm{U}_{\mathrm{t}}$. The Qair value in range 0.219 to $1.093 \mathrm{~m}^{3} / \mathrm{s}$ when AOW flow rate was varied from 100 to 500 $\mathrm{kg} / \mathrm{h}$, while $V_{\text {air }}$ values at 100 to $500 \mathrm{~kg} / \mathrm{h}$ of AOW flow rates was in the range 0.279 to $1.393 \mathrm{~m} / \mathrm{s}$.

The relationship between the AOW capacity entering a spray drying tower and the velocity of the AOW powder particles that fall under a spray drying tower is seen in Figure 5. The antiozonant powder particle velocity decreases from this figure with the increase in the antiozonant wax mass capacity. The velocity of the particles dropping down to the bottom is $5.806 \mathrm{~m} / \mathrm{s}$ with an antiozonant wax flow rate of 100 $\mathrm{kg} /$ hour. Meanwhile, when the antiozonant wax flow rate is $500 \mathrm{~kg} / \mathrm{h}$, the velocity to the 
bottom of the antiozonant wax powder particles will be $4.692 \mathrm{~m} / \mathrm{s}$. The increase in the antiozonant wax flow rate is consistent with the drying air flow rate as per $y=-0.00279 x-$ 6.085. The high flow rate of drying air holds antiozonant wax powder particles down and thus has a low speed. It also seeks to make the antiozonant wax powder product of the same scale and size or uniforms.

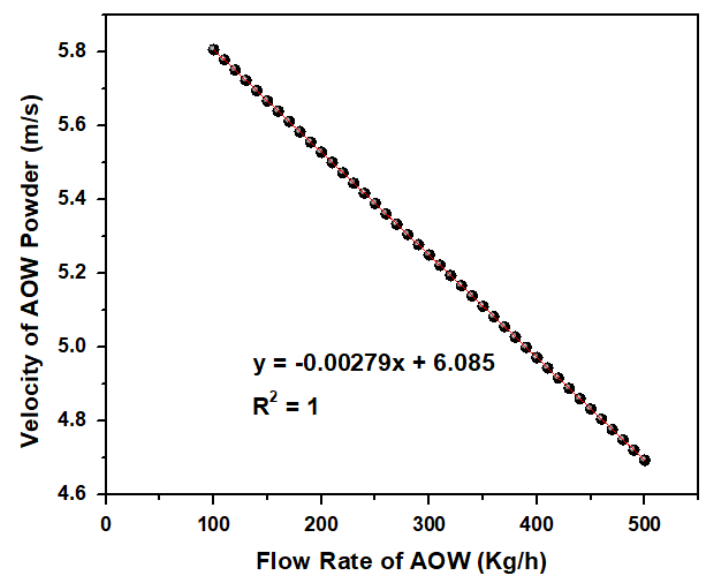

Fig. 5: The relationship between AOW capacity and velocity of AOW powder

\section{Correlation between AOW Capacity and Drying Time}

The drying time can be determined by dividing the height of the spray drying tower by the velocity of AOW powder down the spray drying tower. Figure 6 is the relationship of the antiozonant wax flow rate with the drying air contact time in the spray drying tower. The contact time between antiozonant wax and drying air increases as the antiozonant wax enters the spray drying tower. At a wax flow rate of 100 to 500 $\mathrm{kg} /$ hour, the contact time for the antiozonant wax from liquid to powder was in the range of $1.033-1.279 \mathrm{~s}$. The contact period did not make any noticeable difference since it was closely linked to the previous reason between the antiozonant wax and the drying airflow. Due to a high surface to volume ratio, a fastdrying period can be obtained
(Bellinghausen, 2019). The increase in the flow rate of the antiozonant wax according to equation $y=0.57344+0.41348 e^{0.00107 x}$ is proportional to the drying period for the product requirements.

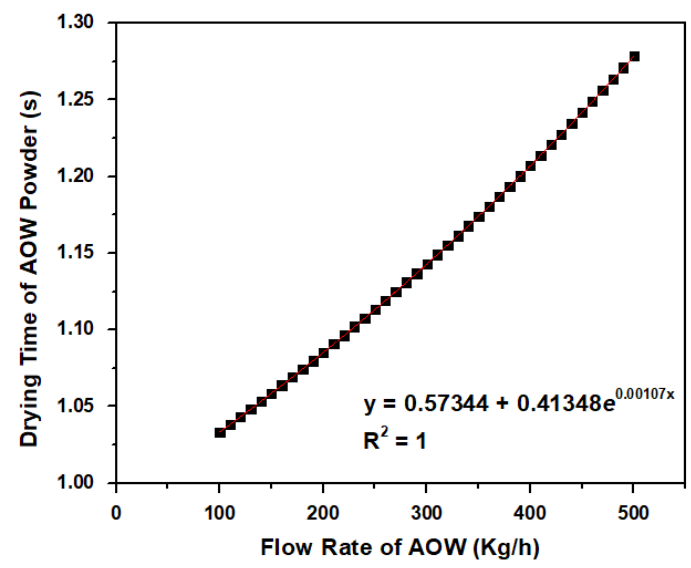

Fig. 6: The relationship between AOW capacity and drying time

\section{Correlation between AOW Capacity and Drying Rate}

Fig. 7 depicts a drying rate curve for the flow rate variation of AOW; it is obvious that the drying rate continues to decrease as the flow rate of AOW that passes to the spray drying tower increases. It explains why the AOW flow rate into the spray tower increases, the drying time increases significantly, according to equation $y=-0.0000043 x+$ 0.0094 . The drying rate was $0.00900 \mathrm{~kg}$ oil $/ \mathrm{kg}$ wax.s when the feed rates were $100 \mathrm{~kg} / \mathrm{h}$. When the feed flow rate is set to $500 \mathrm{~kg} / \mathrm{h}$, the drying rate drops to $0.00727 \mathrm{~kg}$ oil $/ \mathrm{kg}$ wax. s.

A rapidly increasing drying rate, which is inversely linked with the AOW feed flowrate into the spray drying tower, marked the drying phase. A decrease in surface moisture may be ascribed to a mass transfer to the drying air during the drying mechanism at the AOW granules contact, which involves simultaneous heat and mass transfer (Segura-Ponce et al., 2019). 


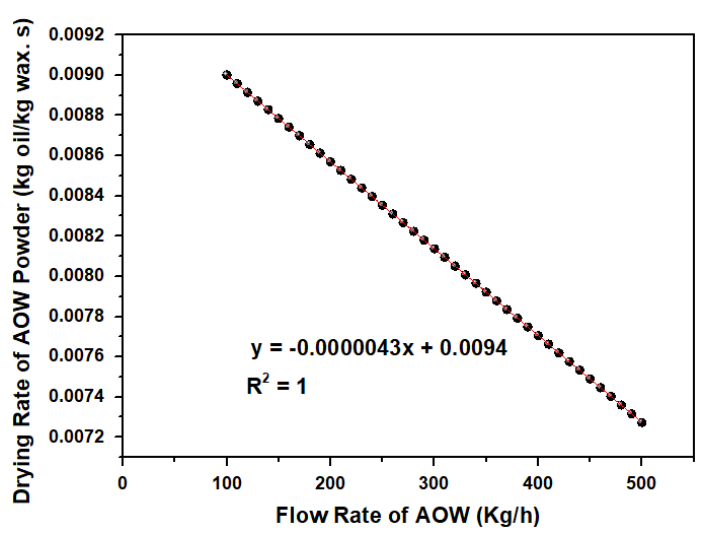

Fig. 7: The relationship between AOW capacity, drying time, and drying rate

\section{Effect of Drying Process on Product Quality}

Powder residual moisture is an essential characteristic that significantly impacts final quality. The outlet temperature in the product was believed to have an impact on residual moisture (Mizrahi et al. 1967), and the value in this experiment was fixed at $40{ }^{\circ} \mathrm{C}$. In this study, the moisture content is linked to the oil content in wax powder, where the final oil content in the AOW powder ranged between $0.08-0.1 \%$ from $1 \%$ in the AOW feed.

A higher feed flow rate was followed by increased drying time. Perhaps AOW powder with a low moisture content was produced to some level. The indication for effective drying operation might be regarded as a powder of AOW with low moisture content but not burned. A drying air rate should be increased in powders with lower moisture content than the lower airflow rate. The longer residence time of the powder product in the spray drying tower can be attributed to this result. Feed density and powder bulk density have a beneficial effect on powder particle size and distribution (Goula and Adamopoulos 2005). Increasing the input temperature at an airflow rate will lead to powders with a higher bulk density (Zareifard et al., 2012), possibly because of the increased rate of evaporation from droplets and thus the production of a porous product. The drying process was also influenced by the stickiness of AOW feed, which is related to viscosity. According to Kudra (2003), stickiness is a phenomenon that causes agglomeration during the drying process, and minimizing stickiness is crucial for industrial drying.

\section{Contribution for Industry}

Antiozonant wax products on the market nowadays are in the shape of granules or prills. This study's spray dryer design focuses on AOW drying, with the product afterwards offered in the market as a finer powder. Industries often determine the size (diameter and height) of the equipment because they adjust to the space available. Aside from spray dryer dimensions, industries also define their product specifications, such as the diameter of AOW powder. Therefore it is important to adjust the operating conditions needed so that the product that comes out is in line with the specifications requested by the industry.

The operating conditions, such as the need for drying air and the drying air temperature required in the drying process, may be optimized by designing a spray dryer. The operating conditions at each flow rate may also be predicted, and other parameters such as contact time, product time down the spray dryer, and drying rate are effectively attained. The energy utilized in the drying process will be more optimum and not excessive if these parameters are optimized. Consequently, production costs, particularly drying costs, can be decreased to a lower level. 


\section{CONCLUSIONS}

The drying airflow rate in the spray drying tower design was assessed for the Antiozonant Wax capacity ranging from 100 to $500 \mathrm{~kg} / \mathrm{hour}$. The drying airflow rate in this system is considered and validated with the AOW temperature data and the required spray drying tower dimensions. The findings revealed that the drying air flow rate was directly proportional to the raw material capacity according to equation $y=9.17 x$. It allows the raw material potential to be inversely proportional to the velocity of the AOW powder at the descent of the spray drying tower according to equation $\mathrm{y}=$ $0,00279 x-6,085$. In addition, the increase in the capacity of raw materials entering the spray drying tower is attributed to an increase in the drying time of the AOW powder according to equation $y=0.57344+$ $0.41348 e^{0.00107 x}$ decrease in drying rate according to equation $y=-0.0000043 x+$ 0.0094. The drying time and drying rate for AOW to become powder is approximately $1.033-1.279 \mathrm{~s}$ and $0.00900-0.00727 \mathrm{~kg}$ oil $/ \mathrm{kg}$ wax.s for AOW flow rates of 100 to 500 $\mathrm{kg} /$ hour. Evaluation of the flow rate of the drying air can aid in designing a spray drying tower such that the products created are of high quality and according to the requirements.

\section{ACKNOWLEDGEMENT}

This research did not receive any specific grant from funding agencies in the public, commercial, or not-for-profit sectors.

\section{REFERENCES}

1. Bellinghausen, R. (2019). "Spray drying from yesterday to tomorrow: An industrial perspective,"

Drying

Technology, 37(5), 612-622.

2. Cataldo, F. (2018). "Early stages of pphenylenediamine antiozonants reaction with ozone: Radical cation and nitroxyl radical formation," Polymer Degradation and Stability, 147, 132-141.

3. Cataldo, F. (2019). "Protection mechanism of rubbers from ozone attack," Ozone: Science \& Engineering, 41(4), 358-368.

4. Cheng, F., Zhou, X., \& Liu, Y. (2018). "Methods for improvement of the thermal efficiency during spray drying," E3S Web of Conferences, 53, 01031. EDP Sciences.

5. Choi, S. S. (1999). "Migration behaviors of antiozonants to the surface in NR vulcanizates, depending on the season: The effect of wax," Journal of applied polymer science, 71(12), 1987-1993.

6. Choi, S. S. (1999). "Wax barrier effect on migration behaviors of antiozonants in NR vulcanizates," Elastomers and Composites, 34(2), 147-155.

7. Crowe, C. T. (1983). "Droplet-gas interaction in counter-current spray dryers," Drying Technology, 1(1), 35-56.

8. de Melo Ramos, F., Ubbink, J., Júnior, V. S., \& Prata, A. S. (2019). "Drying of Maltodextrin solution in a vacuum spray dryer," Chemical Engineering Research and Design, 146, 78-86.

9. Francia, V., Martín, L., Bayly, A. E., \& Simmons, M. J. (2016). "Agglomeration in counter-current spray drying towers. Part A: Particle growth and the effect of nozzle height," Powder Technology, 301, 1330-1343.

10. Francia, V., Martín, L., Bayly, A. E., \& Simmons, M. J. (2016). "Agglomeration in counter-current spray drying towers. Part B: Interaction between multiple 
spraying levels," Powder Technology, 301, 1344-1358.

11. Freund, M. (1982). Paraffin products: properties, technologies, applications, Elsevier Scientific Publishing Company, New York, USA.

12. Goula, A. M., \& Adamopoulos, K. G. (2005). "Spray drying of tomato pulp in dehumidified air: II. The effect on powder properties," Journal of food engineering, 66(1), 35-42.

13. Goula, A. M., \& Adamopoulos, K. G. (2010). "A new technique for spray drying orange juice concentrate," Innovative Food Science \& Emerging Technologies, 11(2), 342-351.

14. Kamaruddin, A. N., Ansarifar, A., Saeed, F., Haile-Meskel, Y., \& Ellis, R. J. (2012). "Effect of different paraffin waxes and antiozonant on the processing and mechanical properties of natural rubber," Journal of Rubber Research, 15(1), 35-45.

15. Keshani, S., Daud, W. R. W., Nourouzi, M. M., Namvar, F., \& Ghasemi, M. (2015). "Spray drying: An overview on wall deposition, process and modeling," Journal of Food Engineering, 146, 152162.

16. Kudra, T. (2003). "Sticky region in drying-definition and identification," Drying Technology, 21(8), 1457-1469.

17. Mizrahi, S., Berk, Z., \& Cogan, U. (1967). "Isolated soybean protein as a banana spray drying aid," Cereal Sci. Today, 12(8), 322.

18. Otolowo, D. T., Olapade, A. A., Oladele, S. O., \& Egbuna, F. (2017). "Drying characteristics and quality evaluation of dehydrated catfish (Clarias gariepinus)," Nutrition \& Food Science, 47, 765-779

19. Sanderson, C., Emmanuel, J., Emmanual, J., \& Campbell, P. (1988). "A historical review of paraffin and its development as an embedding medium," Journal of Histotechnology, 11(1), 61-63.

20. Saha, S., Vineet, K., Bhowmick, A. K., Deuri, A. S., \& Vaidya, D. M. (2021). "Stubble resistance of rubber vulcanizates: Influence of short fiber and resin," Polymer Testing, 94, 107048.

21. Segura-Ponce, L. A., Soto-Pardo, V. A., \& Guzmán-Meza, M. F. (2019). "Characterization of apples (Granny Smith) dried in industrial equipment and the relationship with drying mechanisms," Food Structure, 21, 100119.

22. Sharj-Sharifi, M., Taghvaei-Ganjali, S., \& Motiee, F. (2020). "The effect of protecting waxes on staining antidegradant performance in tyre sidewall formulation," Journal of Rubber Research, 23, 111-124.

23. Sobukola, O. P., \& Olatunde, S. O. (2011). "Effect of salting techniques on salt uptake and drying kinetics of African catfish (Clarias gariepinus)," Food and Bioproducts Processing, 89, 170-177.

24. Trade Map. (2021a). List of products imported by Indonesia detailed products in the following category: 271220 Paraffin wax containing $<0,75 \%$ by weight of oil

25. Trade Map. (2021b). List of products exported by Indonesia detailed products in the following category: 271220 Paraffin wax containing $<0,75 \%$ by weight of oil

26. Ushmarin, N. F., \& Kavun, S. M. (2017). "New antiozonants for rubber compounds based on oxyalkylated derivatives of 4-aminodiphenylamine," International Polymer Science and Technology, 44, 29-36. 
27. Walton, D. E. (2000). "The morphology of spray-dried particles a qualitative view," Drying Technology, 18(9), 1943-1986.

28. Zaky, M. T., Mohamed, N. H., \& Farag, A. S. (2007). "Separation of different paraffin wax grades using two comparative deoiling techniques," Fuel processing technology, 88(9), 913-920.

29. Zareifard, M. R., Niakousari, M., Shokrollahi, Z., \& Javadian, S. (2012). "A feasibility study on the drying of lime juice: the relationship between the key operating parameters of a small laboratory spray dryer and product quality," Food and Bioprocess Technology, 5(5), 1896-1906.

30. Zbiciński, I. (1995). "Development and experimental verification of momentum, heat and mass transfer model in spray drying," The Chemical Engineering Journal and the Biochemical Engineering Journal, 58(2), 123-133. 